\title{
In vivo and in vitro antioxidant effects of three Veronica species
}

Research Article

\author{
Jelena Živković ${ }^{1, \star}$, Tatjana Ćebović ${ }^{\text {, }}$ Zoran Maksimović ${ }^{3}$ \\ 1Institute for Medicinal Plant Research "Dr Josif Pančić," \\ 11000 Belgrade, Serbia \\ 'Department of Biochemistry, School of Medicine, \\ University of Novi Sad, 21102 Novi Sad, Serbia \\ ${ }^{3}$ Department of Pharmacognosy, School of Pharmacy, \\ University of Belgrade, 11221 Belgrade, Serbia
}

Received 18 December 2011; Accepted 12 March 2012

\begin{abstract}
The aim of the present study was to examine the antioxidant activity of three Veronica species (Plantaginaceae). The antioxidant potential of various extracts obtained from aerial flowering parts was evaluated by DPPH-free (1,1-diphenyl-2-picryl- hydrazyl-free) radical scavenging activity and ferric-reducing antioxidant power assays. Considerable antioxidant activity was observed in the plant samples (FRAP values ranged from 0.97 to $4.85 \mathrm{mmol} \mathrm{Fe}{ }^{2+} / \mathrm{g}$, and DPPH IC $\mathrm{C}_{50}$ values from 12.58 to $66.34 \mu \mathrm{g} / \mathrm{ml}$ ); however, these levels were lower than the activity of the control compound butylated hydroxytoluene (BHT) (FRAP: $10.58 \mathrm{mmol}$ $\mathrm{Fe}^{2+} / \mathrm{g}$; DPPH IC $50.9 .57 \mu \mathrm{g} / \mathrm{ml}$ ). Also, the in vivo antioxidant effects were evaluated in several hepatic antioxidant systems in rats (activities of glutathione peroxidase, glutathione reductase, peroxidase, catalase, xanthine oxidase, glutathione content and level of thiobarbituric acid reactive substances) after treatment with different Veronica extracts, or in combination with carbon tetrachloride $\left(\mathrm{CCl}_{4}\right)$. Pretreatment with $100 \mathrm{mg} / \mathrm{kg}$ b.w. of Veronica extracts inhibited $\mathrm{CCl}_{4}$-induced liver injury by decreasing TBA-RS level, increasing GSH content, and bringing the activities of CAT and Px to control levels. The present study suggests that the extracts analyzed could protect the liver cells from $\mathrm{CCl}_{4}$-induced liver damage by their antioxidative effect on hepatocytes.
\end{abstract}

Keywords: Antioxidant activity • Veronica species • Carbon tetrachloride • Lipid peroxidation • Biochemical parameters

(C) Versita Sp. z 0.0 .

\section{Introduction}

Reactive oxygen species (ROS) are generated in living organisms through numerous metabolic pathways. ROS are well recognized for playing a dual role as both deleterious and beneficial species, since they can be either harmful or beneficial to living systems. Beneficial effects of ROS occur at low/moderate concentrations and involve physiological roles in cellular responses to noxia, such as in defence against infectious agents and in the function of a number of cellular signaling systems. On the other hand, the harmful effect of free radicals causing potential biological damage is termed oxidative stress and is defined by excessive formation and/or incomplete removal of ROS [1]. Oxidative stress is an important contributor to the pathophysiology of a variety of pathological conditions including cardiovascular dysfunctions, atherosclerosis, inflammation, carcinogenesis, drug toxicity, reperfusion injury and neurodegenerative diseases [2]. However, our body systems protect themselves against free radical damage by antioxidant enzymes such as superoxide dismutase, catalase, xanthine oxidase, glutathione dependent enzymes, as well as compounds such as ascorbic acid, a-tocopherol and glutathione [3]. Since these protective mechanisms can be disrupted by various pathological phenomena, antioxidant supplements are essential to counter the oxidative damage. Medicinal plants are excellent sources of phytochemicals with potent antioxidant activities [4]. Recently, there has been growing scientific interest to find naturally occurring antioxidants because of established carcinogenicity of synthetic ones [5]. Additionally, it has been suggested that natural antioxidants are more effective than 
the synthesized compound in preventing oxidative stress-related effects due to synergistic interactions among plant components that improve the bioavailability of the antioxidant agents [6].

Veronica (Plantaginaceae) is a genus of 450 species found in temperate regions of both hemispheres [7]. Numerous studies on the identification of secondary metabolites in Veronica species have already been published, with iridoid glucosides (especially benzoic and cinnamic acid esters of catalpol), phenylethanoid and flavonoid glycosides being mainly reported [8]. In addition to the chemotaxonomic and phytochemical importance of the genus, Veronica species are of particular interest given their traditional usage and biological activities. They were selected for our investigation because of their widespread use in traditional medicine worldwide. Some Veronica species are used as diuretics and for their wound-healing properties in traditional Turkish medicine. In Chinese traditional medicine, Veronica species are used as expectorants, restoratives, tonics, and for treatment of influenza and other respiratory diseases [8]. Extracts obtained from above-ground parts of certain Veronica species are used as folk remedies for treatment of various inflammatory ailments, including rheumatism [9]. In addition, stems and leaves of some Veronica species are edible, either raw or cooked [10].

Despite their widespread use, there is a scarcity of physiological evidence to support any claims of therapeutic values for Veronica species. Consequently, the main objective of the present work was to quantify the levels of in vitro antioxidant activity in different extracts of three Veronica species growing wild in Serbia (Veronica jacquinii Baumg., Veronica teucrium L. and Veronica urticifolia Jacq.) by assaying for ferric-reducing antioxidant power (FRAP) and DPPH-free radical scavenging activity (DPPH) as well as to characterize in vivo antioxidant effects using a hepatic antioxidant system assay in rats.

\section{Experimental Procedures}

\subsection{Chemicals}

All reagents used for antioxidant activity assessment were of analytical grade. 1,1-Diphenyl-2-picrylhydrazyl (DPPH), Folin-Ciocalteu reagent, and 2,4,6-tris-(2pyridyl)-s-triazine (TPTZ) were obtained from Sigma Chemical GmbH (Steinheim, Germany), 2-thiobarbituric acid (TBA) was from Reanal (Budapest, Hungary), trichloroacetic acid (TCA) and $\mathrm{FeCl}_{3} \cdot 6 \mathrm{H}_{2} \mathrm{O}$ from LaChema (Neratovice, Czech Republic), $\mathrm{Na}_{2}$ EDTA from Merck (Darmstadt, Germany), $\mathrm{CH}_{3} \mathrm{COONa} \cdot 3 \mathrm{H}_{2} \mathrm{O}$, $\mathrm{Na}_{2} \mathrm{HPO}_{4}, \mathrm{NaOH}$ and $\mathrm{KOH}$ from Zorka-Pharma (Šabac,
Serbia), and $\mathrm{FeSO}_{4} \cdot 7 \mathrm{H}_{2} \mathrm{O}$ from Kemika (Zagreb, Croatia). All solvents used in this investigation were also of analytical grade. Methanol, acetic acid and hydrochloric acid were obtained from Merck (Darmstadt, Germany) and acetone from Zorka-Pharma (Šabac, Serbia). Distilled, deionized water was obtained from a Simplicity 185 purification system (Millipore S.A., Molsheim, France).

\subsection{Plant samples and extraction}

The aerial parts of three Veronica species were collected during their flowering period in June 2008 from two mountain areas in Serbia, Goč in central Serbia and Vršačke Planine in southern Banat. Plant material was taxonomically classified and the voucher specimens of the plant samples were deposited in the Herbarium collection of the Institute of Botany, School of Pharmacy, Belgrade (voucher specimen numbers were VR 157, VR 159 and VR 165 for Veronica teucrium, Veronica jacquinii and Veronica urticifola, respectively). The air-dried plant material was reduced to a fine powder and extracted by maceration method using solvents of varying polarity (water, methanol, $70 \%$ aqueous acetone) in solid:solvent ratio of 1:20 at room temperature for $48 \mathrm{~h}$. Extracts were then evaporated under reduced pressure and stored in a vacuum desiccator.

\subsection{Determination of total phenolic content}

The amount of phenolic compounds in the extract was estimated by using Folin-Ciocalteu reagent as previously described [11]. Diluted extracts $(100 \mu \mathrm{l})$ were mixed with $0.75 \mathrm{ml}$ of Folin-Ciocalteu reagent (previously diluted 10 -fold with distilled water) and incubated at room temperature for $5 \mathrm{~min}$. Subsequently, $0.75 \mathrm{ml}$ of sodium bicarbonate solution $(60 \mathrm{mg} / \mathrm{ml})$ was added. This mixture was stored for 90 minutes at room temperature, and its absorbance was measured at $725 \mathrm{~nm}$. Total phenolic content was calculated from the calibration curve of a gallic acid standard solution and expressed as gallic acid equivalents (GAE) in milligrams per gram extract. All tests were conducted in triplicate.

\subsection{Assay for in vitro ferric-reducing antioxidant power (FRAP assay)}

The total antioxidant capacity of extracts was measured as ferric-reducing antioxidant potential. In this assay, the antioxidant activity is determined on the basis of the ability of the antioxidants within the sample to reduce ferric (III) iron to ferrous (II) iron. This assay depends upon the reduction of ferric 2,4,6-tris(2-pyridyl)-s-triazine [Fe ${ }^{3+}$-TPTZ] to the ferrous 2,4,6-tris(2-pyridyl)-s-triazine [Fe ${ }^{2+}-\mathrm{TPTZ}$ ] complex at low $\mathrm{pH}$, which has an intensive blue color that can be monitored at $593 \mathrm{~nm}$. In brief, 
$100 \mu \mathrm{l}$ of diluted extract was added to $3.0 \mathrm{ml}$ of freshly prepared FRAP-reagent $(25 \mathrm{ml}$ of $300 \mathrm{mM}$ acetate buffer, pH 3.6 plus $2.5 \mathrm{ml}$ of $10 \mathrm{mM}$ TPTZ solution in $40 \mathrm{mM} \mathrm{HCl}$ plus $2.5 \mathrm{ml}$ of $20 \mathrm{mM} \mathrm{FeCl}_{3} \cdot 6 \mathrm{H}_{2} \mathrm{O}$ ). Samples were incubated at $37^{\circ} \mathrm{C}$ and absorbance was recorded at $593 \mathrm{~nm}$. The FRAP-value was calculated from a calibration curve of $\mathrm{FeSO}_{4} \cdot 7 \mathrm{H}_{2} \mathrm{O}$ standard solutions, covering the concentration range 100-1000 $\mu \mathrm{mol} / \mathrm{L}$, and expressed as $\mathrm{mmol} \mathrm{Fe}^{2+} / \mathrm{g}$ dry matter [12]. The relative activity of the samples was compared to that of the control compound butylated hydroxytoluene (BHT).

\subsection{Assay for in vitro DPPH-free radical scavenging activity (DPPH assay)}

Due to its unpaired electron, DPPH radical gives a strong absorption band at $517 \mathrm{~nm}$ (deep violet color). As this electron becomes paired off in the presence of a free radical scavenger, the absorption vanishes and the resulting discoloration is stoichiometric with respect to the number of electrons taken up. Extracts diluted in appropriate solvents $(10-100 \mu \mathrm{L}$, final concentration range: $8-80 \mu \mathrm{g} / \mathrm{ml}$ ) were dispensed into the set of test tubes and final volume was adjusted to $5 \mathrm{ml}$. Finally, $0.5 \mathrm{ml}$ of $0.5 \mathrm{mM}$ methanol DPPH solution was transferred into each test tube. The absorbances were recorded at $517 \mathrm{~nm}$ after $30 \mathrm{~min}$ incubation at room temperature in the dark, against methanol as a blank. The percent inhibition was calculated against the control solution, containing methanol instead of test solution [13]. Butylated hydroxytoluene (BHT) was used as a reference substance.

\subsection{In vivo antioxidant activity}

Dry extracts were dissolved under sonication in water to make $1 \%, 2 \%$ and $5 \%(\mathrm{w} / \mathrm{v})$ solutions, and filtered through a $0.45 \mu \mathrm{m}$ membrane filter. The resulting solutions were stored in the refrigerator $\left(4-8^{\circ} \mathrm{C}\right)$ until analysis.

Animal care and all experimental procedures were conducted in accordance with the Guide for the Care and Use of Laboratory Animal Resources edited by the Commission of Life Sciences, National Research Council. Albino Wistar rats 7-8 week old of both sexes (obtained from Biochemical Laboratory, Medical Faculty, Clinical Centre Novi Sad, University of Novi Sad, Serbia), weighing $200-250 \mathrm{~g}$, were housed individually at $25^{\circ} \mathrm{C}$ with $30-50 \%$ ) humidity and given 4-6 weeks to adapt to a reversed lightdark cycle. The animals were maintained on a standard pellet diet $\left(\mathrm{LM}_{2}\right.$, Veterinarski zavod, Subotica, Serbia) and allowed access to tap water ad libitum.

The extracts were administered intraperitoneally ( $2 \mathrm{ml} / \mathrm{kg}$ body weight) for 7 days. Carbon tetrachloride $\left(\mathrm{CCl}_{4}\right)$, as a well-known radical generator was administered intraperitoneally ( $2 \mathrm{ml} / \mathrm{kg}$ body weight) $24 \mathrm{~h}$ before killing. The animals were randomly divided into eight groups of six, under the following conditions and treatments: in the control group, the animals received $1 \mathrm{ml} / \mathrm{kg} \mathrm{b.w}$. distilled water for 7 days; in the control $+\mathrm{CCl}_{4}$, the animals were treated with $1 \mathrm{ml} / \mathrm{kg}$ b.w. distilled water for 7 days and $2 \mathrm{mg} / \mathrm{kg}$ b.w. $\mathrm{CCl}_{4}$ (day 7), $24 \mathrm{~h}$ before killing; the experimental animals in groups E1-E3 were given $2 \mathrm{ml} / \mathrm{kg}$ b.w. of 1,2 and $5 \%$ extract solutions (doses of 20, 40 and $100 \mathrm{mg} / \mathrm{kg} \mathrm{b.w.),}$ respectively, for 7 days. Finally, in groups $\mathrm{E} 1+\mathrm{CCl}_{4}$ to $\mathrm{E} 3+\mathrm{CCl}_{4}$, the animals were treated with the same doses of investigated extracts, followed by $2 \mathrm{ml} / \mathrm{kg} \mathrm{b.w}$. $\mathrm{CCl}_{4}$ (day 7), $24 \mathrm{~h}$ before killing.

At the end of the experiment (day 8) the animals were anaesthetized with isofluorane (1.5\% in oxygen) for a period not exceeding $10 \mathrm{~min}$, decapitated and exsanguinated. The liver weight was taken after removal of the gall bladder. Samples weighing $1 \mathrm{~g}$ were homogenized with TRIS-HCl/saccharose solution (50 mmol/L; $0.25 \mathrm{~mol} / \mathrm{L}, \mathrm{pH} 7.40$ ), 1:3, $4^{\circ} \mathrm{C}$, using a glass Potter-Elvehjem homogenizer set. The resulting homogenate was centrifuged at $1500 \times \mathrm{xg}$ for $10 \mathrm{~min}$ and protein concentrations were determined by the biuret reaction using bovine serum albumin as the standard [14].

\subsection{Biochemical assays}

The activity of xanthine oxidase (XOD) was determined following the Bergmayer method [15], catalase (CAT) according to Beers and Sizer [16], peroxidase (Px) according to Simon et al., [17], glutathione peroxidase (GSHPx) according to Beuthler [18] and glutathione reductase (GR) according to Goldberg and Spooner [19]. The amounts of reduced glutathione (GSH) were also determined [20] as well as the level of thiobarbituric acid reactive substances (TBA-RS) using the Buege and Aust protocol [21].

\subsection{Statistical analysis}

All data are presented as mean \pm standard deviations. One way analysis of variance (ANOVA) was used to detect any significant differences among different means as well as interactions between the variables used in biochemical analyses. Statistically significant effects were further analyzed and means were compared using Tukey and Bonferroni tests. A level of $\mathrm{P}<0.05$ was taken as statistically significant. $I_{50}$ values, which denote the concentration of sample required to scavenge $50 \%$ DPPH radicals, were calculated after the performance of PROBIT analysis, from the calibration equation of transformed data [22]. Correlations between variables were established by regression analysis. 


\section{Results and Discussion}

Since most antioxidant activities from plant sources are correlated with phenolic-type compounds [23] we first determined total phenolic content (TPC) in extracts obtained from aerial flowering parts of Veronica species. As the difference in polarities of solvents used for plant sample extraction might influence the solubility of chemical constituents in sample, each Veronica sample was extracted using three different solvents: methanol, aqueous acetone (acetone:distilled water, 70:30 v/v) and distilled water. The content of phenolic compounds $(\mathrm{mg} / \mathrm{g})$ in plant extracts, determined from regression equation of calibration curve $(y=0.0609 x-0.0002$, $\left.R^{2}=0.999\right)$ and expressed in gallic acid equivalents (GAE), varied between 116 and 201 (Table 1). The highest levels of TPC were observed in extracts obtained from aerial flowering parts of Veronica jacquinii. Our results indicate the most effective solvent was aqueous acetone and resulted in extracts containing the highest TPC levels, while the lowest values were obtained for water extracts. The reason for the high extraction efficiency with aqueous solvents could be primarily due to the water-soluble nature of plant phenolics enhanced by the presence of an organic solvent, which facilitates solubilization through penetration in plant tissues [24].

The antioxidant activity of the extracts was initially evaluated by their ability to scavenge the stable DPPH free radicals. DPPH is organic free radical extensively used to evaluate scavenging activity of antioxidants because it is sensitive enough to detect active ingredients at low concentrations [25]. Although the investigated extracts of Veronica species exhibited a significant dose dependent inhibition of DPPH activity, the activity was not stronger than that of the standard compound BHT. The concentrations required for scavenging $50 \%$ of $\mathrm{DPPH}$ radicals ranged from 12.58 to $66.34 \mu \mathrm{g} / \mathrm{ml}$ (Table 1), while the $\mathrm{IC}_{50}$ value of BHT was $9.57 \mu \mathrm{g} / \mathrm{ml}$. The extracts of Veronica teucrium exhibited the strongest inhibitory effect, as the $\mathrm{IC}_{50}$ values were achieved with the lowest concentrations. The weakest antiradical activity was shown by the water extracts.

On the basis of reports that showed the antioxidant activity of plants was closely associated with their reducing power [26], we further evaluated the reducing power of the extracts obtained from Veronica species using the FRAP assay. FRAP is a simple and rapid method that measures the reducing capability of antioxidants and screens for their ability to maintain the redox status in cells [27]. The FRAP values for the investigated extracts were found to be between 0.97 and $4.85 \mathrm{mmol} \mathrm{Fe}^{2+} / \mathrm{g}$. The highest reducing power was shown for Veronica teucrium extracts, which is consistent with the free radical-scavenging capacity observed in the DPPH assay. Also, among the examined herbal extracts, $70 \%$ aqueous acetone extracts exhibited the most potent antioxidant and free radical scavenging activity.

The total phenolic content of the plant extracts showed a weak correlation with the antioxidant activity. This weak relationship may be caused by different factors; for example, flavonoids with a certain structure and hydroxyl position in the molecule can only act as proton donors and show antiradical activity. Moreover, measurement of phenolics using the Folin-Ciocalteu method might not be a good indicator of antioxidant capacity because this assay estimates total phenolics present in the extract, but is subjected to interference, giving elevated apparent phenolic concentrations [28]. In addition, the reason for weak correlation could be the synergism of polyphenolic compounds with one another, or with other components present in an extract

\begin{tabular}{c|cccc}
\hline Sample & Extract & DPPH IC $_{50}$ values $(\mu \mathrm{g} / \mathrm{ml})$ & FRAP values $\left(\mathrm{mmol} \mathrm{Fe}^{2+} / \mathrm{g}\right)$ & $\begin{array}{c}\text { Total phenolic content } \\
(\mathrm{mg} \text { GAE/g dry extract) }\end{array}$ \\
\hline \hline Veronica jacquinii & Methanol & 31.47 & 3.46 & 195 \\
Veronica jacquinii & 70\% aqueous acetone & 25.24 & 3.74 & 201 \\
Veronica jacquinii & Water & 53.97 & 1.88 & 175 \\
Veronica teucrium & Methanol & 22.20 & 4.71 & 157 \\
Veronica teucrium & $70 \%$ aqueous acetone & 12.58 & 4.85 & 172 \\
Veronica teucrium & Water & 16.19 & 4.06 & 116 \\
Veronica urticifolia & Methanol & 51.41 & 1.71 & 168 \\
Veronica urticifolia & 70\% aqueous acetone & 22.70 & 2.10 & 171 \\
Veronica urticifolia & Water & 66.34 & 0.97 & 144 \\
BHT (standard) & - & 9.57 & 10.58 & - \\
\hline
\end{tabular}

Table 1. Antioxidant activity and phenolic content of tested Veronica species. 
that may contribute to the overall observed antioxidant activity [29]. Previous studies have demonstrated that compounds usually present in Veronica spp., such as the phenylethanoid acteoside [30] and the iridoid compounds minecoside, specioside, amphicoside and verminoside [31], exhibit strong radical scavenging activity against DPPH radical.

The results obtained from in vitro analyses show that extracts of the Veronica plant samples are efficient antioxidants. Because of variations in antioxidant activities often observed using different in vitro models, there are also requisite in vivo tests used to confirm antioxidant activity. The $\mathrm{CCl}_{4}$-induced hepatotoxicity model is extensively used to evaluate antioxidant effects of drugs and plant extracts [32]. In the presence of oxygen, trichlormethyl radical $\left(\mathrm{CCl}_{3}{ }^{*}\right.$; relatively unreactive), a metabolic product of carbon tetrachloride $\left(\mathrm{CCl}_{4}\right)$ activation, forms highly reactive trichlormethyl peroxyl radicals $\left(\mathrm{CCl}_{3} \mathrm{O}^{*}\right)$ which interact with polyunsaturated fatty acids and cause lipid peroxidation. In $\mathrm{CCl}_{4}$-induced hepatotoxicity, the balance between ROS production and endogenous antioxidant defenses may be lost. "Oxidative stress" occurs, which through a series of events deregulates the cellular functions leading to hepatic necrosis [33]. Thus, the antioxidative and free radical scavenging mechanism plays an important role in the protection against $\mathrm{CCl}_{4}$-induced hepatic damage.

The effects of Veronica extracts on several biochemical parameters of oxidative stress were evaluated in the liver homogenate of rats treated with $\mathrm{CCl}_{4}$ as a free radical generator. LPx intensity, GSH content, and GSHPx, GR, Px, XOD and CAT activities were analyzed (Tables 2 and 3 ). Intraperitoneal administration of extracts was selected instead of oral application in order to avoid possible chemical changes upon oral consumption of the extracts. Compared with the control group, the $\mathrm{CCl}_{4}$-intoxicated animals showed a significant reduction of CAT, Px, and GR activities and GSH levels, together with a significant increase in GSHPx activity and LPx content. No significant change of XOD activity was observed.

Xanthine oxidase is the enzyme that utilizes hypoxanthine or xanthine as a substrate and $\mathrm{O}_{2}$ as a cofactor to produce superoxide $\left({ }^{*} \mathrm{O}_{2}{ }^{-}\right)$and uric acid [34]. It serves as an important biological source of oxygenderived free radicals that contribute to oxidative damage to living tissues. The present research confirmed previous research showing that $\mathrm{CCl}_{4}$ does not alter the activity of hepatic XOD [35]. Similar results were observed in animals treated with different doses of Veronica extracts, with the exception of $1 \%$ water extract of Veronica jacquinii applied at a dose of $20 \mathrm{mg} / \mathrm{kg}$ b.w., which, after simultaneous application with $\mathrm{CCl}_{4}$, caused a statistically significant decrease $(F=6.036, P<0.05)$ of $X O D$ activity compared with the control group.

Catalase (CAT) is an antioxidant enzyme which catalyzes the decomposition of $\mathrm{H}_{2} \mathrm{O}_{2}$ to water and oxygen and thus protects cells from oxidative damage produced by $\mathrm{H}_{2} \mathrm{O}_{2}$ [36]. Administration of Veronica extracts (groups E1-E3) during the course of this experiment led to slight but insignificant changes of enzyme activity in the liver homogenate. Furthermore, the dosage regimen had no influence on the observed activity of CAT, as no correlation between applied doses and this parameter could be established. Treatment with $\mathrm{CCl}_{4}$ alone caused a substantial (roughly 3-fold) decrease in CAT activity, while combined treatment of Veronica extracts and $\mathrm{CCl}_{4}$ resulted in a dose-dependent increase of CAT enzyme activity. All of the tested Veronica extracts at a dose of $100 \mathrm{mg} / \mathrm{kg}$ b.w. significantly reduced the effects of $\mathrm{CCl}_{4}$ in the animals, keeping the CAT activity at the physiological level recorded in the control group. Our results showed no significant differences between the effects of extracts on CAT activity depending on type of solvent or plant material used in the extraction procedure.

Peroxidase $(\mathrm{Px})$ is an enzyme that catalyzes the reduction of hydroperoxides, including hydrogen peroxides, and functions to protect cells from peroxidative damage [37]. Intraperitoneal administration of a $2 \mathrm{ml} / \mathrm{kg} \mathrm{CCl}$ dose caused a 2-fold decrease of Px activity in liver homogenate, which could indicate the presence of an increased production of hydrogen peroxide $\left(\mathrm{H}_{2} \mathrm{O}_{2}\right)$. All the Veronica extracts in combination with $\mathrm{CCl}_{4}$ yielded a dose dependant increase of $\mathrm{Px}$ enzyme activity. Application of extracts at doses of $100 \mathrm{mg} / \mathrm{kg}$ b.w., with the exception of the Veronica jacquinii water extract sample, significantly reduced the influence of $\mathrm{CCl}_{4}$ in the animals, keeping the activity of hepatic peroxidase close to the physiological level recorded in the control group (Table 2). For the investigated extracts of Veronica jacquinii, statistically significant differences were observed (except in group E1) in their effects on Px activity depending on the solvent used in the extraction procedure Our results showed that water extract exhibited the weakest stimulation of Px activity.

Glutathione (GSH) is an important cellular, nonenzymatic antioxidant, and it plays a major role in protecting cells against oxidative stress. The depletion of hepatic GSH has been shown to be associated with an enhanced toxicity of chemicals, including $\mathrm{CCl}_{4}$ [38]. Intraperitoneal administration of a single $2 \mathrm{ml} / \mathrm{kg}$ b.w. dose of $\mathrm{CCl}_{4}$ caused a substantial (roughly 7 -fold) drop in GSH levels, indicating significant damage to the hepatic cells. It is a generally accepted view that free radicals generated in the process of $\mathrm{CCl}_{4}$ biotransformation and ROS produced during $\mathrm{CCl}_{4}$-stimulated lipid peroxidation 


\begin{tabular}{|c|c|c|c|c|}
\hline Sample & Group & $X O D$ & CAT & Px \\
\hline & $\begin{array}{c}\text { Control } \\
\text { Control }+\mathrm{CCl}_{4}\end{array}$ & $\begin{array}{l}1.93 \pm 0.17 \\
1.89 \pm 0.20\end{array}$ & $\begin{array}{c}9.56 \pm 2.25 \\
3.35 \pm 1.88^{a^{\star \star}}\end{array}$ & $\begin{array}{l}10.77 \pm 1.89 \\
4.92 \pm 1.03^{a^{\star \star}}\end{array}$ \\
\hline $\begin{array}{l}\text { Veronica jacquinii (methanolic } \\
\text { extract) }\end{array}$ & $\begin{array}{c}\mathrm{E}_{1} \\
\mathrm{E}_{2} \\
\mathrm{E}_{3} \\
\mathrm{E}_{1}+\mathrm{CCl}_{4} \\
\mathrm{E}_{2}+\mathrm{CCl}_{4} \\
\mathrm{E}_{3}+\mathrm{CCl}_{4}\end{array}$ & $\begin{array}{l}2.01 \pm 0.21 \\
1.87 \pm 0.14 \\
1.97 \pm 0.19 \\
1.82 \pm 0.09 \\
1.94 \pm 0.18 \\
2.03 \pm 0.23\end{array}$ & $\begin{array}{c}9.62 \pm 2.28 \\
11.62 \pm 1.74 \\
11.15 \pm 2.30 \\
4.22 \pm 2.66^{a^{*}} \\
5.95 \pm 1.50^{a^{*}, b^{*}} \\
8.46 \pm 2.67^{b^{\star}}\end{array}$ & $\begin{array}{c}11.15 \pm 2.30 \\
8.46 \pm 2.67^{\mathrm{b}^{\star}} \\
13.83 \pm 4.64 \\
10.71 \pm 2.27^{\mathrm{b}^{\star \star}} \\
6.85 \pm 0.92^{\mathrm{a}^{\star}} \\
16.10 \pm 3.09^{\mathrm{a}^{\star \star}}\end{array}$ \\
\hline $\begin{array}{l}\text { Veronica jacquinii (70\% } \\
\text { aqueous acetone extract) }\end{array}$ & $\begin{array}{c}\mathrm{E}_{1} \\
\mathrm{E}_{2} \\
\mathrm{E}_{3} \\
\mathrm{E}_{1}+\mathrm{CCl}_{4} \\
\mathrm{E}_{2}+\mathrm{CCl}_{4} \\
\mathrm{E}_{3}+\mathrm{CCl}_{4}\end{array}$ & $\begin{array}{l}2.02 \pm 0.27 \\
1.79 \pm 0.23 \\
2.03 \pm 0.24 \\
1.79 \pm 0.14 \\
1.93 \pm 0.20 \\
2.02 \pm 0.24\end{array}$ & $\begin{array}{c}9.55 \pm 1.97 \\
10.29 \pm 1.92 \\
10.79 \pm 1.74 \\
4.10 \pm 2.48^{\mathrm{a}^{*}} \\
6.58 \pm 2.16^{a^{*}, b^{*}} \\
8.34 \pm 2.81^{\mathrm{b}^{*}}\end{array}$ & $\begin{array}{c}9.29 \pm 0.78 \\
10.56 \pm 1.44 \\
10.66 \pm 1.49 \\
4.62 \pm 0.76^{a^{\star \star}} \\
7.57 \pm 0.97^{a^{*}} \\
9.93 \pm 1.46^{b^{\star \star}}\end{array}$ \\
\hline $\begin{array}{l}\text { Veronica jacquinii (water } \\
\text { extract) }\end{array}$ & $\begin{array}{c}\mathrm{E}_{1} \\
\mathrm{E}_{2} \\
\mathrm{E}_{3} \\
\mathrm{E}_{1}+\mathrm{CCl}_{4} \\
\mathrm{E}_{2}+\mathrm{CCl}_{4} \\
\mathrm{E}_{3}+\mathrm{CCl}_{4}\end{array}$ & $\begin{array}{c}1.95 \pm 0.20 \\
1.84 \pm 0.31 \\
2.14 \pm 0.34 \\
1.68 \pm 0.20^{a^{*}} \\
1.85 \pm 0.26 \\
2.06 \pm 0.44\end{array}$ & $\begin{array}{c}9.99 \pm 2.34 \\
10.58 \pm 2.42 \\
11.10 \pm 2.39 \\
3.91 \pm 2.02^{a^{*}} \\
6.12 \pm 1.17^{2^{*}, b^{*}} \\
8.30 \pm 3.01^{b^{*}}\end{array}$ & $\begin{array}{c}8.42 \pm 1.41^{\mathrm{a}^{*}} \\
8.16 \pm 1.42^{\mathrm{a}^{*}} \\
8.84 \pm 1.95 \\
2.00 \pm 0.83^{a^{\star *}, \mathrm{~b}^{\star *}} \\
4.11 \pm 1.27^{\mathrm{a}^{\star *}} \\
7.54 \pm 1.46^{a^{*, \mathrm{~b}^{*}}}\end{array}$ \\
\hline $\begin{array}{l}\text { Veronica teucrium (methanolic } \\
\text { extract) }\end{array}$ & $\begin{array}{c}\mathrm{E}_{1} \\
\mathrm{E}_{2} \\
\mathrm{E}_{3} \\
\mathrm{E}_{1}+\mathrm{CCl}_{4} \\
\mathrm{E}_{2}+\mathrm{CCl}_{4} \\
\mathrm{E}_{3}+\mathrm{CCl}_{4}\end{array}$ & $\begin{array}{l}1.90 \pm 0.09 \\
1.86 \pm 0.13 \\
1.77 \pm 0.17 \\
1.84 \pm 0.08 \\
1.86 \pm 0.24 \\
1.70 \pm 0.18\end{array}$ & $\begin{array}{c}9.25 \pm 1.95 \\
10.80 \pm 2.27 \\
10.61 \pm 1.82 \\
3.77 \pm 1.79^{a^{\star \star}} \\
5.63 \pm 1.48^{a^{\star}, b^{\star}} \\
7.83 \pm 2.83^{b^{\star *}}\end{array}$ & $\begin{array}{c}10.71 \pm 2.50 \\
10.54 \pm 2.07 \\
12.72 \pm 1.69 \\
3.38 \pm 0.47^{a^{\star \star}} \\
5.86 \pm 2.01^{a^{\star}} \\
10.31 \pm 2.33^{b^{\star \star}}\end{array}$ \\
\hline $\begin{array}{l}\text { Veronica teucrium ( } 70 \% \\
\text { aqueous acetone extract) }\end{array}$ & $\begin{array}{c}\mathrm{E}_{1} \\
\mathrm{E}_{2} \\
\mathrm{E}_{3} \\
\mathrm{E}_{1}+\mathrm{CCl}_{4} \\
\mathrm{E}_{2}+\mathrm{CCl}_{4} \\
\mathrm{E}_{3}+\mathrm{CCl}_{4}\end{array}$ & $\begin{array}{l}1.94 \pm 0.09 \\
1.81 \pm 0.11 \\
1.77 \pm 0.17 \\
1.90 \pm 0.12 \\
1.79 \pm 0.23 \\
1.72 \pm 0.24\end{array}$ & $\begin{array}{c}9.30 \pm 1.97 \\
10.88 \pm 2.37 \\
10.76 \pm 2.22 \\
3.81 \pm 2.07^{\mathrm{a}^{* \star}} \\
5.79 \pm 1.62^{2^{*}, b^{*}} \\
8.98 \pm 4.27^{\mathrm{b}^{*}}\end{array}$ & $\begin{array}{c}11.12 \pm 2.85 \\
11.74 \pm 1.65 \\
12.61 \pm 2.41 \\
4.09 \pm 0.98^{a^{\star \star}} \\
4.99 \pm 1.46^{a^{* \star}} \\
8.49 \pm 2.51^{\mathrm{b}^{\star}}\end{array}$ \\
\hline $\begin{array}{c}\text { Veronica teucrium (water } \\
\text { extract) }\end{array}$ & $\begin{array}{c}\mathrm{E}_{1} \\
\mathrm{E}_{2} \\
\mathrm{E}_{3} \\
\mathrm{E}_{1}+\mathrm{CCl}_{4} \\
\mathrm{E}_{2}+\mathrm{CCl}_{4} \\
\mathrm{E}_{3}+\mathrm{CCl}_{4}\end{array}$ & $\begin{array}{l}1.86 \pm 0.18 \\
1.81 \pm 0.19 \\
1.71 \pm 0.18 \\
1.84 \pm 0.20 \\
1.78 \pm 0.19 \\
1.71 \pm 0.27\end{array}$ & $\begin{array}{c}9.37 \pm 1.45 \\
11.12 \pm 3.31 \\
10.88 \pm 3.30 \\
3.71 \pm 2.43^{a^{*}} \\
6.63 \pm 1.82^{\alpha^{*} b^{*}} \\
9.67 \pm 2.76^{b^{\star *}}\end{array}$ & $\begin{array}{c}9.69 \pm 1.05 \\
11.42 \pm 1.40 \\
8.25 \pm 2.36 \\
3.57 \pm 1.11^{a^{\star \star}} \\
4.67 \pm 1.84^{a^{\star \star}} \\
7.89 \pm 2.11^{\mathrm{b}^{\star}}\end{array}$ \\
\hline $\begin{array}{c}\text { Veronica urticifolia (methanolic } \\
\text { extract) }\end{array}$ & $\begin{array}{c}\mathrm{E}_{1} \\
\mathrm{E}_{2} \\
\mathrm{E}_{3} \\
\mathrm{E}_{1}+\mathrm{CCl}_{4} \\
\mathrm{E}_{2}+\mathrm{CCl}_{4} \\
\mathrm{E}_{3}+\mathrm{CCl}_{4}\end{array}$ & $\begin{array}{l}1.91 \pm 0.03 \\
1.98 \pm 0.10 \\
1.99 \pm 0.22 \\
1.82 \pm 0.11 \\
1.83 \pm 0.09 \\
1.80 \pm 0.24\end{array}$ & $\begin{array}{c}9.29 \pm 1.74 \\
10.80 \pm 2.06 \\
10.79 \pm 1.69 \\
3.80 \pm 1.87^{a^{\star \star}} \\
5.61 \pm 1.15^{a^{\star}, b^{\star}} \\
7.73 \pm 2.15^{b^{\star \star}}\end{array}$ & $\begin{array}{l}10.99 \pm 2.05 \\
11.07 \pm 1.17 \\
12.05 \pm 1.96 \\
4.19 \pm 1.42^{\mathrm{a}^{\star \star}} \\
4.65 \pm 1.49^{\mathrm{a}^{\star \star}} \\
8.91 \pm 1.599^{\mathrm{b}^{\star \star}}\end{array}$ \\
\hline $\begin{array}{l}\text { Veronica urticifolia (70\% } \\
\text { aqueous acetone extract) }\end{array}$ & $\begin{array}{c}\mathrm{E}_{1} \\
\mathrm{E}_{2} \\
\mathrm{E}_{3} \\
\mathrm{E}_{1}+\mathrm{CCl}_{4} \\
\mathrm{E}_{2}+\mathrm{CCl}_{4} \\
\mathrm{E}_{3}+\mathrm{CCl}_{4}\end{array}$ & $\begin{array}{l}1.87 \pm 0.13 \\
1.99 \pm 0.12 \\
2.02 \pm 0.26 \\
1.86 \pm 0.03 \\
1.78 \pm 0.12 \\
1.79 \pm 0.21\end{array}$ & $\begin{array}{c}9.71 \pm 2.00 \\
11.08 \pm 2.77 \\
10.76 \pm 2.17 \\
4.95 \pm 2.72^{\mathrm{a}^{*}} \\
5.99 \pm 1.66^{a^{*}, \mathrm{~b}^{*}} \\
7.54 \pm 1.80^{\mathrm{b}^{*}}\end{array}$ & $\begin{array}{c}10.29 \pm 2.24 \\
11.29 \pm 1.58 \\
11.75 \pm 3.05 \\
4.19 \pm 1.79^{a^{\star \star}} \\
6.12 \pm 1.42^{a^{\star \star}} \\
10.56 \pm 2.20^{0^{\star \star}}\end{array}$ \\
\hline $\begin{array}{c}\text { Veronica urticifolia (water } \\
\text { extract) }\end{array}$ & $\begin{array}{c}\mathrm{E}_{1} \\
\mathrm{E}_{2} \\
\mathrm{E}_{3} \\
\mathrm{E}_{1}+\mathrm{CCl}_{4} \\
\mathrm{E}_{2}+\mathrm{CCl}_{4} \\
\mathrm{E}_{3}+\mathrm{CCl}_{4}\end{array}$ & $\begin{array}{l}1.88 \pm 0.17 \\
1.98 \pm 0.12 \\
1.98 \pm 0.25 \\
1.84 \pm 0.19 \\
1.86 \pm 0.17 \\
1.82 \pm 0.22\end{array}$ & $\begin{array}{c}9.38 \pm 1.94 \\
10.56 \pm 2.30 \\
10.82 \pm 2.08 \\
3.59 \pm 1.60^{a^{\star *}} \\
6.89 \pm 1.34^{a^{*}, b^{\star}} \\
8.51 \pm 2.60^{b^{*}}\end{array}$ & $\begin{array}{c}9.13 \pm 1.00 \\
10.39 \pm 1.42 \\
10.48 \pm 2.85 \\
3.86 \pm 0.96^{a^{\star \star}} \\
5.36 \pm 1.62^{a^{\star \star}} \\
8.86 \pm 2.46^{b^{\star}}\end{array}$ \\
\hline
\end{tabular}

Table 2. Effect of various extracts of tested Veronica species and $\mathrm{CCl}_{4}$ on the biochemical parameters in the rat liver homogenate. Note: The results are presented as mean \pm standard deviation for six rats. Activities of xanthine oxidase (XOD), catalase (CAT) and peroxidase $(P x)$ are expressed in $\mathrm{nmol} / \mathrm{mg}$ of protein $\mathrm{min}^{-1}$; aSignificantly different from the control group at $P^{\text {; }}{ }^{b}$ Significantly different from the control $+\mathrm{CCl}_{4}$ group at $P ;{ }^{\star} P<0.05 ;{ }^{\star \star} P<0.001$ 


\begin{tabular}{|c|c|c|c|c|c|}
\hline Sample & Group & GSH & GSHPx & GR & TBA-RS \\
\hline \multirow{7}{*}{$\begin{array}{c}\text { Veronica jacquinii (methanolic } \\
\text { extract) }\end{array}$} & $\begin{array}{c}\text { Control } \\
\text { Control }+\mathrm{CCl}_{4}\end{array}$ & $\begin{array}{c}4.97 \pm 1.37 \\
0.73 \pm 0.40^{a^{* *}}\end{array}$ & $\begin{array}{c}8.50 \pm 1.27 \\
21.27 \pm 6.67^{\star \star \star}\end{array}$ & $\begin{array}{c}6.10 \pm 1.60 \\
1.23 \pm 0.55^{a^{\star \star}}\end{array}$ & $\begin{array}{c}2.98 \pm 0.81 \\
9.66 \pm 1.41^{1^{\star \star}}\end{array}$ \\
\hline & & $5.53 \pm 0.95$ & $8.52 \pm 0.78$ & $6.01 \pm 0.67$ & $2.66 \pm 0.29$ \\
\hline & $\mathrm{E}_{2}$ & $5.59 \pm 0.83$ & $8.31 \pm 0.65$ & $6.50 \pm 0.94$ & $2.10 \pm 0.14^{\mathrm{a}^{\star}}$ \\
\hline & $\mathrm{E}_{3}^{2}$ & $6.78 \pm 1.25^{a^{*}}$ & $6.85 \pm 0.92^{\mathrm{a}^{\star}}$ & $6.86 \pm 0.99$ & $1.55 \pm 0.33^{a^{\star}}$ \\
\hline & $\mathrm{E}_{1}+\mathrm{CCl}_{4}$ & $0.59 \pm 0.18^{\mathrm{a}^{* k}}$ & $25.23 \pm 2.64^{\mathrm{a}^{\star \star}}$ & $1.23 \pm 0.53^{\mathrm{a}^{\star \star}}$ & $11.59 \pm 1.48^{a^{* *}, b^{*}}$ \\
\hline & $\mathrm{E}_{2}+\mathrm{CCl}_{4}^{4}$ & $2.23 \pm 0.55^{a^{\star}, b^{\star \star}}$ & $20.47 \pm 2.86^{\mathrm{a}^{\star \star}}$ & $1.69 \pm 0.73^{a^{\star \star}}$ & $8.08 \pm 0.93^{a^{\star *}, b^{*}}$ \\
\hline & $\mathrm{E}_{3}^{2}+\mathrm{CCl}_{4}^{4}$ & $4.48 \pm 0.84^{b^{\star \star}}$ & $16.10 \pm 3.09^{a^{\star \star}}$ & $3.33 \pm 1.30^{a^{*}, b^{*}}$ & $3.13 \pm 1.43^{b^{* \star}}$ \\
\hline \multirow{6}{*}{$\begin{array}{l}\text { Veronica jacquinii (70\% aqueous } \\
\text { acetone extract) }\end{array}$} & $E_{1}$ & $4.26 \pm 0.53$ & $8.43 \pm 1.05$ & $6.00 \pm 0.35$ & $1.98 \pm 0.59^{a^{*}}$ \\
\hline & $\mathrm{E}_{2}$ & $4.35 \pm 0.80$ & $8.64 \pm 0.81$ & $6.63 \pm 0.69$ & $1.83 \pm 0.45^{\mathrm{a}^{\star}}$ \\
\hline & $\mathrm{E}_{3}^{2}$ & $4.18 \pm 0.37$ & $7.26 \pm 1.80$ & $6.60 \pm 1.24$ & $1.78 \pm 0.18^{a^{*}}$ \\
\hline & $\mathrm{E}_{1}+\mathrm{CCl}_{4}$ & $0.70 \pm 0.22^{\mathrm{a}^{* *}}$ & $27.28 \pm 2.64^{\mathrm{a}^{\star \star}}$ & $1.24 \pm 0.54^{\mathrm{a}^{\star \star}}$ & $7.18 \pm 2.45^{a^{*}}$ \\
\hline & $\mathrm{E}_{2}^{1}+\mathrm{CCl}_{4}^{4}$ & $1.74 \pm 0.50^{a^{* *}, b^{*}}$ & $22.07 \pm 1.96^{\mathrm{a}^{\star \star}}$ & $2.84 \pm 1.07^{a^{\star \star}, b^{*}}$ & $4.57 \pm 2.09^{\mathrm{b}^{\star *}}$ \\
\hline & $\mathrm{E}_{3}^{2}+\mathrm{CCl}_{4}^{4}$ & $3.74 \pm 0.31^{b^{\star *}}$ & $15.77 \pm 1.30^{\mathrm{a}^{\star *}}$ & $4.40 \pm 1.18^{\mathrm{a}^{\star}, \mathrm{b}^{* *}}$ & $2.03 \pm 0.89^{b^{\star *}}$ \\
\hline \multirow{6}{*}{ Veronica jacquinii (water extract) } & $E_{1}$ & $4.39 \pm 0.43$ & $8.14 \pm 1.00$ & $6.12 \pm 0.77$ & $1.90 \pm 0.78^{a^{*}}$ \\
\hline & $\mathrm{E}_{2}$ & $4.59 \pm 0.49$ & $8.39 \pm 0.85$ & $6.52 \pm 1.03$ & $1.24 \pm 0.79^{\mathrm{a}^{*}}$ \\
\hline & & $5.08 \pm 0.92$ & $8.41 \pm 1.16$ & $7.55 \pm 0.89^{a^{*}}$ & $0.67 \pm 0.36^{a^{\star \star}}$ \\
\hline & $\mathrm{E}_{1}+\mathrm{CCl}_{4}$ & $0.62 \pm 0.16^{\mathrm{a}^{\star \star}}$ & $22.62 \pm 6.13^{a^{\star \star}}$ & $1.41 \pm 0.42^{\mathrm{a}^{\star \star}}$ & $8.84 \pm 1.82^{\mathrm{a}^{\star \star}}$ \\
\hline & $\mathrm{E}_{2}+\mathrm{CCl}_{4}^{4}$ & $1.24 \pm 0.38^{a^{\star \star}, b^{\star}}$ & $18.70 \pm 3.79^{\mathrm{a}^{\star \star}}$ & $2.08 \pm 0.65^{a^{* *}, b^{*}}$ & $6.48 \pm 1.18^{a^{* *}, b^{*}}$ \\
\hline & $\mathrm{E}_{3}+\mathrm{CCl}_{4}^{4}$ & $4.10 \pm 0.58^{b^{\star \star}}$ & $11.14 \pm 2.18^{a^{\star} b^{*}}$ & $3.70 \pm 1.57^{a^{*}, b^{*}}$ & $0.89 \pm 0.79^{a^{*}, b^{* *}}$ \\
\hline \multirow{6}{*}{$\begin{array}{l}\text { Veronica teucrium (methanolic } \\
\text { extract) }\end{array}$} & $E_{1}$ & $5.59 \pm 0.92$ & $8.56 \pm 0.78$ & $6.01 \pm 0.83$ & $2.70 \pm 0.58$ \\
\hline & $\mathrm{E}_{2}$ & $5.51 \pm 0.99$ & $8.36 \pm 1.61$ & $6.74 \pm 0.67$ & $1.81 \pm 0.73^{a^{*}}$ \\
\hline & $\mathrm{E}_{3}^{2}$ & $5.92 \pm 1.56$ & $6.84 \pm 0.10^{\mathrm{a}^{\star}}$ & $7.24 \pm 0.89$ & $2.97 \pm 0.58$ \\
\hline & $\mathrm{E}_{1}+\mathrm{CCl}_{4}$ & $0.73 \pm 0.16^{a^{\star \star}}$ & $24.18 \pm 4.97^{\mathrm{a}^{\star \star}}$ & $1.07 \pm 0.43^{a^{\star \star}}$ & $9.52 \pm 1.32^{2^{\star \star}}$ \\
\hline & $\mathrm{E}_{2}+\mathrm{CCl}_{4}^{4}$ & $2.19 \pm 0.48^{a^{* *}, b^{* *}}$ & $17.36 \pm 2.17^{\mathrm{a}^{\star \star}}$ & $1.92 \pm 0.85^{a^{\star \star}}$ & $8.64 \pm 1.60^{\mathrm{a}^{\star \star *}}$ \\
\hline & $\mathrm{E}_{3}^{2}+\mathrm{CCl}_{4}^{4}$ & $4.31 \pm 0.58^{b^{\star *}}$ & $11.19 \pm 1.82^{a^{*}, b^{*}}$ & $3.64 \pm 1.34^{a^{*}, b^{*}}$ & $4.09 \pm 1.44^{b^{\star *}}$ \\
\hline \multirow{6}{*}{$\begin{array}{l}\text { Veronica teucrium (70\% } \\
\text { aqueous acetone extract) }\end{array}$} & $E_{1}$ & $5.11 \pm 0.70$ & $8.70 \pm 1.04$ & $6.01 \pm 1.68$ & $3.01 \pm 0.73$ \\
\hline & $E_{2}$ & $4.57 \pm 0.39$ & $7.69 \pm 1.57$ & $6.99 \pm 0.91$ & $2.93 \pm 0.13$ \\
\hline & $\mathrm{E}_{3}^{2}$ & $3.81 \pm 0.75$ & $7.15 \pm 1.47$ & $7.14 \pm 1.75$ & $2.89 \pm 0.21$ \\
\hline & $\mathrm{E}_{1}+\mathrm{CCl}_{4}$ & $0.51 \pm 0.28^{a^{* *}}$ & $24.08 \pm 2.84^{\mathrm{a}^{\star \star}}$ & $1.20 \pm 0.43^{\mathrm{a}^{\star \star}}$ & $8.19 \pm 2.29^{\mathrm{a}^{\star \star}}$ \\
\hline & $\mathrm{E}_{2}+\mathrm{CCl}_{4}^{4}$ & $1.70 \pm 0.34^{a^{* *}, b^{*}}$ & $20.57 \pm 1.98^{a^{\star \star}}$ & $2.00 \pm 0.97^{\mathrm{a}^{\star \star}}$ & $5.62 \pm 0.56^{a^{* *}, b^{\star *}}$ \\
\hline & $\mathrm{E}_{3}^{2}+\mathrm{CCl}_{4}^{4}$ & $4.63 \pm 0.31^{b^{\star \star}}$ & $9.30 \pm 3.13^{\mathrm{b}^{*}}$ & $3.62 \pm 0.86^{a^{*} \cdot b^{\star *}}$ & $3.11 \pm 1.06^{b^{\star *}}$ \\
\hline \multirow{6}{*}{ Veronica teucrium (water extract) } & $E_{1}$ & $3.85 \pm 0.62$ & $8.31 \pm 0.49$ & $6.15 \pm 0.62$ & $1.60 \pm 0.83^{\mathrm{a}^{\star \star}}$ \\
\hline & $\mathrm{E}_{2}$ & $4.74 \pm 0.42$ & $8.49 \pm 2.07$ & $6.79 \pm 0.52$ & $2.00 \pm 1.30^{\mathrm{a}}$ \\
\hline & $\mathrm{E}_{3}^{2}$ & $4.25 \pm 0.23$ & $7.42 \pm 1.44$ & $6.98 \pm 1.03$ & $0.57 \pm 0.36^{\mathrm{a}}$ \\
\hline & $\mathrm{E}_{1}+\mathrm{CCl}_{4}$ & $0.57 \pm 0.27^{\mathrm{a}^{\star \star}}$ & $21.22 \pm 2.94^{\mathrm{a}^{\star *}}$ & $1.25 \pm 0.44^{\mathrm{a}^{\star \star}}$ & $8.72 \pm 1.49^{a^{\star *}}$ \\
\hline & $\mathrm{E}_{2}+\mathrm{CCl}_{4}^{4}$ & $1.61 \pm 0.36^{a^{* *}, b^{*}}$ & $18.75 \pm 4.30^{\mathrm{a}^{\star *}}$ & $2.01 \pm 0.70^{\mathrm{a}^{\star \star}}$ & $4.50 \pm 1.15^{a^{*}, b^{* *}}$ \\
\hline & $\mathrm{E}_{3}^{2}+\mathrm{CCl}_{4}^{4}$ & $4.39 \pm 0.37^{b^{\star \star}}$ & $11.28 \pm 2.54^{a^{* *}, b^{*}}$ & $4.18 \pm 1.49^{a^{*}, b^{*}}$ & $1.12 \pm 0.60^{a^{*}, b^{* \star}}$ \\
\hline \multirow{6}{*}{$\begin{array}{c}\text { Veronica urticifolia (methanolic } \\
\text { extract) }\end{array}$} & $E_{1}$ & $4.96 \pm 1.30$ & $8.80 \pm 1.11$ & $5.99 \pm 0.65$ & $2.53 \pm 1.13$ \\
\hline & $E_{2}^{1}$ & $5.84 \pm 1.16$ & $8.59 \pm 1.48$ & $6.53 \pm 0.62$ & $2.16 \pm 0.67$ \\
\hline & $\mathrm{E}_{3}^{2}$ & $7.25 \pm 1.24^{\mathrm{a}^{*}}$ & $7.49 \pm 1.21$ & $6.60 \pm 0.94$ & $1.16 \pm 0.49^{\mathrm{a}^{\star \star}}$ \\
\hline & $\mathrm{E}_{1}+\mathrm{CCl}_{4}$ & $0.73 \pm 0.25^{\mathrm{a}^{* k}}$ & $21.32 \pm 4.43^{a^{\star \star}}$ & $1.06 \pm 0.37^{\mathrm{a}^{\star \star}}$ & $10.56 \pm 1.48^{a^{\star *}}$ \\
\hline & $\mathrm{E}_{2}+\mathrm{CCl}_{4}^{4}$ & $1.90 \pm 0.35^{a^{\star \star}, b^{\star \star}}$ & $18.05 \pm 2.79^{a^{\star \star}}$ & $1.68 \pm 0.65^{a^{\star \star}}$ & $9.21 \pm 1.55^{a^{\star \star}}$ \\
\hline & $\mathrm{E}_{3}^{2}+\mathrm{CCl}_{4}^{4}$ & $3.19 \pm 1.05^{\mathrm{a}^{\star}, \mathrm{b}^{\star *}}$ & $12.15 \pm 3.64^{a^{*}, b^{*}}$ & $3.02 \pm 1.22^{a^{*}, b^{* *}}$ & $5.22 \pm 1.37^{a^{*}, b^{* *}}$ \\
\hline \multirow{6}{*}{$\begin{array}{l}\text { Veronica urticifolia (70\% } \\
\text { aqueous acetone extract) }\end{array}$} & $E_{1}$ & $5.67 \pm 0.87$ & $8.79 \pm 1.11$ & $6.16 \pm 1.40$ & $3.10 \pm 0.29$ \\
\hline & $\mathrm{E}_{2}$ & $6.51 \pm 1.11$ & $9.57 \pm 1.67$ & $6.88 \pm 1.17$ & $2.90 \pm 0.48$ \\
\hline & $\mathrm{E}_{3}^{2}$ & $7.61 \pm 0.52^{\mathrm{a}^{*}}$ & $6.42 \pm 1.66^{\mathrm{a}^{*}}$ & $7.16 \pm 1.01$ & $2.83 \pm 0.36$ \\
\hline & $\mathrm{E}_{1}+\mathrm{CCl}_{4}$ & $0.54 \pm 0.22^{a^{\star \star}}$ & $21.87 \pm 2.55^{a^{\star \star}}$ & $1.12 \pm 0.60^{\mathrm{a}^{* \star}}$ & $8.01 \pm 0.93^{a^{\star \star}, b^{*}}$ \\
\hline & $\mathrm{E}_{2}^{1}+\mathrm{CCl}_{4}^{4}$ & $1.73 \pm 0.29^{\mathrm{a}^{* \star}, \mathrm{b}^{* *}}$ & $20.07 \pm 1.86^{\mathrm{a}^{\star \star}}$ & $1.17 \pm 0.82^{\mathrm{a}^{\star \star}}$ & $6.21 \pm 1.11^{a^{\star \star}, b^{\star \star}}$ \\
\hline & $\mathrm{E}_{3}^{2}+\mathrm{CCl}_{4}^{4}$ & $3.21 \pm 0.69^{a^{*}, b^{* *}}$ & $14.25 \pm 2.40^{\mathrm{a}^{* *}, \mathrm{~b}^{*}}$ & $2.62 \pm 0.76^{a^{* *}, b^{*}}$ & $4.03 \pm 0.78^{a^{*}, b^{* *}}$ \\
\hline \multirow{6}{*}{ Veronica urticifolia (water extract) } & $\mathrm{E}_{1}$ & $4.34 \pm 0.28$ & $9.27 \pm 0.83$ & $6.51 \pm 0.99$ & $1.64 \pm 0.44^{\mathrm{a}^{\star}}$ \\
\hline & $\mathrm{E}_{2}$ & $4.42 \pm 0.70$ & $8.30 \pm 0.89$ & $7.46 \pm 0.50^{\mathrm{a}^{*}}$ & $1.26 \pm 0.38^{\mathrm{a}^{* \star}}$ \\
\hline & $\mathrm{E}_{3}^{2}$ & $4.72 \pm 0.26$ & $7.24 \pm 0.73$ & $7.07 \pm 1.08$ & $1.32 \pm 0.93^{\mathrm{a}^{\star}}$ \\
\hline & $\mathrm{E}_{1}+\mathrm{CCl}_{4}$ & $0.69 \pm 0.22^{a^{* *}}$ & $24.45 \pm 3.47^{a^{\star \star}}$ & $1.38 \pm 0.56^{\mathrm{a}^{\star \star}}$ & $8.68 \pm 0.95^{\mathrm{a}^{\star \star}}$ \\
\hline & $\mathrm{E}_{2}^{1}+\mathrm{CCl}_{4}^{4}$ & $1.84 \pm 0.61^{1^{* *}, b^{*}}$ & $19.00 \pm 2.27^{a^{\star \star}}$ & $1.66 \pm 1.25^{a^{\star \star}}$ & $6.87 \pm 1.55^{a^{\star *}, b^{*}}$ \\
\hline & $\mathrm{E}_{3}+\mathrm{CCl}_{4}^{4}$ & $3.20 \pm 0.25^{a^{*}, b^{* *}}$ & $14.75 \pm 1.48^{\mathrm{a}^{\star \star}, \mathrm{b}^{\star}}$ & $3.53 \pm 0.94^{\mathrm{a}^{*}, \mathrm{~b}^{\star *}}$ & $1.98 \pm 0.92^{b^{\star *}}$ \\
\hline
\end{tabular}

Table 3. Effect of various extracts of tested Veronica species and $\mathrm{CCl} 4$ on the biochemical parameters in the rat liver homogenate.

Note: The results are presented as mean \pm standard deviation for six rats. Level of thiobarbituric acid reactive substances (TBA-RS) is expressed in nmolMDA/mg of protein; MDA, malonyldialdehyde. Content of hepatic reduced glutathione (GSH) is expressed in nmo/GSH/mg of protein. Activities of glutathione peroxidase (GSHPx) and glutathione reductase (GR) are expressed in nmol/mg of protein min $^{-1}$; a Significantly different from the control group at $P$; ${ }^{b}$ Significantly different from the control $+C \mathrm{Cl}$ group at $P$; ${ }^{*} P<0.05$; ${ }^{*} P<0.001$ 
react with reduced glutathione, leading to its depletion. As presented in Tables 3, application of extracts of Veronica jacquinii and Veronica teucrium at a dose $100 \mathrm{mg} / \mathrm{kg}$ b.w. cancelled out the effect of $\mathrm{CCl}_{4}$ in the animals, keeping the $\mathrm{GSH}$ content in the liver homogenate close to the level recorded in the control group. This increase in hepatic GSH levels may be due to de novo GSH synthesis or GSH regeneration.

Glutathione peroxidase (GSH-Px) catalyzes the reduction of hydroperoxides by glutathione. Its main function is to protect against the damaging effect of endogenously formed hydroperoxides [36]. Administration of methanolic extracts (group E3) from species Veronica jacquinii and Veronica teucrium, and acetone aqueous extract from Veronica urticifolia at a dose of $100 \mathrm{mg} / \mathrm{kg} \mathrm{b.w}$. significantly decreased the GSH-Px activity. Other investigated extracts did not cause notable changes. The treatment of animals with $\mathrm{CCl}_{4}$ caused a 2.5-fold increase of GSH-Px activity in the liver homogenate, while simultaneous application of extracts and $\mathrm{CCl}_{4}$ showed a dose-dependent decrease of GSH-Px activity. All of the extracts applied at doses of $100 \mathrm{mg} / \mathrm{kg}$ b.w. decreased the activity of GSH-Px, but only the acetone aqueous extract of Veronica teucrium was able to diminish the harmful effect of excessive production of free radicals provoked by $\mathrm{CCl}_{4}$, which was in agreement with the effect of this extract on GSH content. The type of solvent used for extract preparation did not significantly influence the effects of Veronica extracts on GSH-Px activity, with the exception of the E3 group of animals treated with Veronica jacquinii extracts where the methanolic extract showed the highest inhibition of GSH-Px activity.

The main biological role of glutathione reductase (GR) is maintenance of high GSH and low GSSG levels [39]. It reduces requirements in GSH synthesis. After a single dose of $\mathrm{CCl}_{4}$, an almost 5-fold decrease in enzyme activity was observed. Significant decreases in glutathione levels were correlated with a reduction in GR activity. Simultaneous application of extracts and $\mathrm{CCl}_{4}$ led to dose-dependent increases in GR activity, but still significantly different from its control levels. Although corresponding values remained lower when compared with basal GR activity, the protective effect of tested Veronica extracts was unambiguous. According to our results no significant differences were observed in effects of examined extracts on GR activity depending on type of solvent used in the extraction procedure.

Carbon-tetrachloride and its metabolites are capable of initiating a chain of lipid peroxidation reactions by abstracting hydrogen from polyunsaturated fatty acids (PUFA). Peroxidation of lipids, particularly those containing PUFA, can dramatically change the properties of biological membranes resulting in severe cell damage and play a significant role in pathogenesis of some diseases [33]. Enhanced lipid peroxidation is a measure of membrane damage as well as alteration in structure and function in cell membranes. This is an autocatalytic process, which is a common consequence of cell death. It has been proposed that one of the principal causes of $\mathrm{CCl}_{4}$-induced liver injury is lipid peroxidation by free radical derivatives of $\mathrm{CCl}_{4}$ [40]. The LPx intensity was measured in terms of TBA-RS formation, and it was significantly lower in the liver homogenate of animals treated with Veronica water extracts. For the aqueous acetone plant extracts, significant differences were observed in their effects depending on the Veronica species used in the extraction procedure. The decrease in TBA-RS level was most pronounced for those extracts obtained from aerial flowering parts of Veronica jacquinii. A single $2 \mathrm{ml} / \mathrm{kg}$ b.w. dose of $\mathrm{CCl}_{4}$ resulted in a strong induction of TBA-RS formation compared to the untreated control. In animals that received a combined treatment, the water extracts were most effective in inhibiting the TBA-RS formation induced by $\mathrm{CCl}_{4}$. Veronica jacquinii and Veronica teucrium extracts, when applied at doses of $100 \mathrm{mg} / \mathrm{kg}$ b.w., decreased the levels of TBA-RS to those observed in the control group, or in case of water extracts to level significantly lower than the control. Among extracts obtained from aerial flowering parts of Veronica urticifolia, only the water extract (dose $100 \mathrm{mg} / \mathrm{kg} \mathrm{b.w.)}$ showed significant inhibition of TBA-RS formation. By decreasing $\mathrm{CCl}_{4}$-induced LPx, tested extracts showed a hepatoprotective effect.

Our results demonstrate that Veronica plant extracts have a protective role in oxidative stress. This conclusion is based on results from multiple assay systems (TBA-RS, GSH, GR, GSHPx, XOD, CAT and PX) after treatment with different extracts of aerial flowering parts of tested Veronica species in combination with $\mathrm{CCl}_{4}$. The results indicate toxicity of $\mathrm{CCl}_{4}$, probably due to the radicals involved in its metabolism. Examined extracts from three Veronica species reduced radical species, helping to keep normal levels of enzymatic, non-enzymatic antioxidants and lipid peroxidation. The extracts possess optimal antioxidative properties, which could exert an ameliorating action in the pathological alterations. According to the results obtained for the values of TBA-RS level and GSH content it can be concluded that antioxidant effects of Veronica jacquinii and Veronica teucrium were similar to each other and higher than that of Veronica urticifolia.

Further work can be carried out on the isolation, purification and quantification of the active principles from the aerial parts of tested Veronica species and on determining possible synergistic interactions among extract components for their antioxidative activity. 


\section{Acknowledgements}

This work is supported by grant No. 143012, Ministry of Education and Science, Republic of Serbia. The authors

References

[1] Valko M., Leibfritz D., Moncol J., Cronin M.T.D., Mazur M., Telser J., Free radicals and antioxidants in normal physiological functions and human disease, Int. J. Biochem. Cell Biol., 2007, 39, 44-83

[2] Aroma O.I., Free radicals, oxidative stress and antioxidants in human health and disease, J. Amer. Oil Chem. Soc., 1998, 75, 199-212

[3] Datta K., Sinha S., Chattopadhyay P., Reactive oxygen species in health and disease, The Natl. Med. J. India, 2000, 13, 304-310

[4] Dragland S., Senoo H., Wake K., Holte K., Blomhoff R., Several culinary and medicinal herbs are important sources of dietary antioxidants, J. Nutr., 2003, 20, 1286-1290

[5] Valyova M., Hadjimitova V., Stoyanov S., Ganeva Y., Petrov T., Petrov I., Free radicals scavenging activity of extracts from Bulgarian Veronica officinalis L. and GC-MS analysis of ethanol extract, Inter. J. of Aesth. \& Antiag. Med., 2009, 2(1)

[6] Vitaglione P., Marisco F., Caporaso N., Fogliano V., Dietary antioxidant compound and liver health, Crit. Rev. Food Sci. Nutr., 2004, 44, 575-586

[7] Taskova R.M., Kokubin T., Ryan K.G., GamockJones P.J., Jensen S.R., Phenylethanoid and iridoid glycosides in the New Zealand Snow Hebes (Veronica, Plantaginaceae), Chem. Pharm. Bull., 2010, 58, 703-711

[8] Harput U.S., Genc Y., Khan N., Saracoglu I., Radical scavenging effects of different Veronica species, Rec. Nat. Prod., 2011, 5, 100-107

[9] Küpeli E., Harput U.S., Varel M., Yesilada E., Saracogly I., Bioassay guided isolation of iridoid glucosides with antionociceptive and antiinflammatory activities from Veronica anagallisaquatica L., J. Ethnopharmacol., 2005, 102, 170176

[10] Hong D.Y., Fischer M.A., Veronica, In: Zheng-Yi W., Raven P.H. (Eds.), Flora of China, Vol. 18, Science Press, Beijing, 1998

[11] Velioglu Y.S., Mazza G., Gao L., Oomah B.D., Antioxidant activity and total phenolics in selected fruits, vegetables and grain products, J. Agric. Food Chem., 1998, 46, 4113-4117

[12] Pellegrini N., Serafini M., Colombi B., Del Rio D., Salvatore S., Bianchi M., et al., Total antioxidant also wish to express their thanks to Prof. Dr. Branislava Lakušić for identification of the plant material.

capacity of plant foods, beverages and oils consumed in Italy assessed by three different in vitro assays, J. Nutr., 2003, 133, 2812-2819

[13] Cuendet M., Hostettmann K., Potterat O., Dyatmiko W., Iridoid glucosides with free radical scavenging properties from Fagraea blumei, Helv. Chim. Acta, 1997, 80, 1144-1152

[14] Wood E.J., Practical biochemistry for colleges, $1^{\text {st }}$ ed., Pergamon Press, Oxford, 1989

[15] Bergmayer U.H., Methods of enzymatic analysis, $1^{\text {st }}$ ed., Verlag Chemie, Weinheim, 1970

[16] Beers R.F.J., Sizer J.W., Spectrophotometric method for measuring of breakdown of hydrogen peroxide by catalase, J. Biol. Chem., 1950, 195, 133-140

[17] Simon L.M., Fatrai Z., Jonas D.J., Matkovics B., Study of metabolism enzymes during the development of Phaseolus vulgaris, Biochem. Physiol. Pfl., 1974, 166, 389-393

[18] Beuthler E., Duron O., Kelly B., Improved methods for the determination of blood glutathione, J. Lab. Clin. Med., 1983, 61, 882-889

[19] Goldberg D.M., Spooner R.J., Glutathione reductase. In: Bergmayer H.U. (Ed) Methods of Enzymatic Analysis, Vol. 3, Weinheim, Basel, 1983

[20] Beutler E., Glutathione reductase, glutathione peroxidase, catalase, glutathione, In: Beutler E. (Ed.), Red cell metabolism: a manual of biochemical methods, Grune and Stratton, New York, 1984

[21] Buege A.L., Aust D.S., Microsomal lipid peroxidation. In: Fleisher S., Parker L. (Eds), Methods in Enzymology, Academic Press, New York, 1978

[22] Yugoslav Pharmacopoeia, $5^{\text {th }}$ ed., Federal Institute for Public Health \& Contemporary Administration, Belgrade, 2000

[23] Bravo L., Polyphenols: chemistry, dietary sources, metabolism, and nutritional significance, Nutr. Rev., 1998, 56, 317-333

[24] Moure A., Cruz J.M., Franco D., Dominguez J.M., Siherio J., Dominguez $\mathrm{H}$., Natural antioxidants from residual sources, Food Chem., 2001, 72, 145-171

[25] Zou Y., Lu Y., Wei D., Antioxidant activity of flavonoid-rich extract of Hypericum perforatum $L$. in vitro, J. Agric. Food Chem., 2004, 52, 5032-5039 
[26] Meir S., Kanner J., Akiri B., Hadas S.P., Determination and involvement of aqueous reducing compounds in oxidative defence systems of various senescing leaves, J. Agric. Food Chem., 1995, 43, 1813-1815

[27] Phipps S.M., Sharaf M.H.M., Butterweck V., Assessing antioxidant activity in botanicals and other dietary supplements, Pharmacopoeial Forum, 2007, 33, 810-814

[28] Ghimire B.K., Seong E.S., Kim E.H., Ghimeray A.K., Yu C.Y., Ghimire B.K., et al., A comparative evaluation of the antioxidant activity of some medicinal plants populary used in Nepal, J. Med. Plant Res., 2011, 5, 1884-1891

[29] Ordoñez A.A.L., Gomez J.D., Vattuone M.A., Isla M.I., Antioxidant activities of Sechium edule (Jacq.) Swartz extracts, Food Chem., 2006, 97, 452-458

[30] Chiou W.F., Lin L.C., Chen C.F., The antioxidant and free radical scavenging properties of acteoside, Chin. Pharm. J. (Taipei), 2003, 55, 347-353

[31] Kwak J.H., Kim H.J., Lee K.H., Kang S.C., Zee O.P., Antioxidative iridoid glycosides and phenolic compounds from Veronica peregrina, Arch. Pharm. Res., 2009, 32, 207-213

[32] Kaurinović B., Popović M., Vlaisavljević S., Rašeta M., Antioxidant activities of Melittitis melissophyllum L. (Lamiaceae), Molecules, 2011, 16, 3152-3167

[33] Aleynik S.I., Leo M.A., Ma X., Aleynik M.K., Lieber C.S., Polyenylphosphatidylcholine prevent carbon tetrachloride-induced lipid peroxidation while it attenuates liver fibrosis, J. Hepatol., 1997, 27, 554-561

[34] Chung H.Y., Baek B.S., Song S.H., Kim M.S., Huh J.I., Shim K.H., et al., Xanthine dehydrogenase/ xanthine oxidase and oxidative stress, Age, 1997, 20, 127-140

[35] Ćebović T., Spasić S., Popović M., Borota J., Leposavić G., The European mistletoe (Viscum album L.) grown on plums extract inhibits $\mathrm{CCl} 4$ induced liver damage in rats, Fresen. Environ. Bull., 2006, 15, 393-400

[36] Preethi K.C., Kuttan G., Kuttan R., Antioxidant potential of an extract of Calendula officinalis flowers in vitro and in vivo, Pharmaceut. Biol., 2006, 44, 691-697

[37] Sandhir R., Gill K.D., Hepatoprotective effects of LIV-52 on ethanol induced liver damage in rats, Indian J. Exp. Biol., 1999, 37, 762-766

[38] Tirmenstein M.A., Nicholls-Grzemski F.A., Zhang G.J., Fariss M.W., Glutathione depletion and the production of reactive oxygen species in isolated hepatocyte suspensions, Chem. Biol. Interact., 2000, 127, 201-217

[39] Kulinsky V.I., Kolesnichenko L.S., The glutathione system. II. Other enzymes, thiol-disulfide metabolism, inflammation, and immunity, functions, Biochem. (Mosc.) Suppl. Ser. B: Biomed. Chem., 2009, 3, 211-220

[40] Recknagel R.O., Glende J.E.A., Ugazio G., Mechanisms of carbon tetrachloride toxicity, Pharmacol. \& Therapeut., 1989, 43, 139-154 